\title{
PEMENUHAN HAK KONSTITUSIONAL MASYARAKAT PENGANUT KEPERCAYAAN LOKAL DALAM PEMILIHAN UMUM
}

\author{
Muhammad Yusrizal Adi Syaputra \\ Fakultas Hukum, Universitas Medan Area \\ Email: Yusrizal.adi@gmail.com \\ Mirza Nasution \\ Fakultas Hukum, Universitas Sumatera Utara \\ Email: Mirzanasution@ymail.com
}

\begin{abstract}
AbstraK
Kedudukan Negara Indonesia sebagai negara hukum yang melaksanakan prinsip demokrasi secara tegas diatur oleh UUD 1945. Konsekuensi Indonesia sebagai negara hukum adalah adanya persamaan didepan hukum dan pemerintahan bagi setiap warga negara sebagaimana yang diatur dalam Pasal 27 ayat (1) UUD 1945. Salah satu akibat hukum yang ditimbulkan dari Pasal 27 ayat 1 UUD 1945 adalah bahwa setiap warga negara yang memenuhi syarat untuk memilih dalam pemilihan umum haru diakomodir hak pilih dan memilihnya oleh negara. Kelompok masyarakat penganut kepercayaan lokal di Indonesia adalah bagian dari warga negara Indonesia yang memiliki persamaan kedudukan didepan hukum dan pemerintahan. Kelompok masyarakat penganut kepercayaan lokal Indonesia yang tersebar di beberapa daerah seperti masyarakat penganut parmalim di Sumatera Utara, Sunda Wiwitan di Jawa Barat, Sapto Darmo di Jawa Tengah dan Masyarakat penganut Marapu di Sumba dan lainnya. Dalam konteks pelaksanaan hak-hak politik warga negara masih ditemukan ketidakadilan dan diskriminasi diantara masyarakat mayoritas kepada masyarakat minoritas melalui regulasi dan kebijakan terkait pemilihan umum, misalnya masih banyak ditemukan masyarakat yang menganut kepercayaan lokal tidak memiliki KTP Elektronik sehingga tidak terdaftar sebagai pemilih tetap untuk memilih dalam pemlihan umum. Penelitian ini mengkaji tentang Bagaimana perlindungan hak konstitusional penganut aliran kepercayaan dalam pemilihan umum berdasarkan sistem ketatanegaraan Indonesia? Dan apakah Setelah diterbitkannya Putusan Mahkamah Konstitusi Nomor perkara 97/PUU$\mathrm{XIV} / 2016$, penganut aliran kepercayaan dapat menjadi pemilih dalam pemilihan umum tanpa harus mengadopsi salah satu dari ke-enam agama yang diakui di Indonesia.
\end{abstract}

Kata Kunci: Hak Konstitusional, Pemilihan Umum, Penganut Aliran Kepercayaan.

\begin{abstract}
The position of Indonesia as a legal state that implements democratic principles is strictly regulated by the 1945 Constitution. The consequence of Indonesia as a legal state is the existence of equality before law and government for every citizen as stipulated in Article 27 paragraph (1) of the 1945 Constitution. arising from Article 27 paragraph 1 of the 1945 Constitution is that every citizen who meets the requirements to vote in the general election must be accommodated by the right to vote and vote by the state. Community groups adhering to local beliefs in Indonesia are part of Indonesian citizens who have equal position before law and government. Community
\end{abstract}


groups adhering to Indonesian local beliefs are scattered in several regions such as the parmalim adherents in North Sumatra, Sunda Wiwitan in West Java, Sapto Darmo in Central Java and the Marapu community in Sumba and others. In the context of implementing political rights of citizens there is still found injustice and discrimination among the majority community to minority communities through regulations and policies related to elections, for example there are still many people who hold local beliefs do not have Electronic KTPs so that they are not registered as permanent voters to vote in general election. This study examines how to protect the constitutional rights of adherents of the belief flow in general elections based on the Indonesian constitutional system? And whether after the issuance of the Constitutional Court Decision Case Number 97 / PUU-XIV / 2016, believers can become voters in general elections without having to adopt one of the six religions recognized in Indonesia.

Keywords: Constitutional Rights, General Elections, Adherents of Beliefs

\section{A. PENDAHULUAN}

\section{Latar Belakang}

Kedudukan Negara Indonesia sebagai Negara Hukum berbentuk Republik secara tegas memegang prinsip demokrasi/kedaulatan rakyat. Prinsip demokrasi/kerakyatan tersebut berada dalam norma fundamental negara yakni sila ke-empat Pancasila: "kerakyatan yang dipimpin oleh hikmat kebijaksanaan dalam permusyawaratan perwakilan”. Sila keempat tersebut kemudian dituangkan kedalam konstitusi Indonesia, Pasal 1 ayat (2) Undang-Undang Dasar 1945 (UUD 1945) yang berbunyi: “kedaulatan berada ditangan rakyat dan dilaksanakan menurut Undang-Undang Dasar. Implementasi dari kedaulatan tersebut salah satunya adalah dengan diterapkannya pemilihan umum (Pemilu) yang demokratis untuk memilih Presiden dan wakil Presiden, Anggota Dewan Perwakilan Rakyat (baik di tingkat pusat, provinsi, dan kabupaten/kota), Anggota Dewan Perwakilan Daerah, Gubernur dan Wakil Gubernur, serta Bupati dan Wakil Bupati/Walikota dan Wakil Walikota.

Konsekuensi Indonesia sebagai negara hukum adalah penempatan kedudukan warga negara yang sama didepan hukum dan pemerintahan sebagaimana diatur dalam 
Pasal 27 ayat (1) UUD 1945 yang berbunyi: "segala warga negara bersamaan kedudukannya di dalam hukum dan pememerintahan dan wajib menjunjung hukum dan pemerintahan itu dengan tidak ada kecualinya”. Salah satu akibat hukum yang ditimbulkan dari Pasal 27 ayat 1 tersebut adalah setiap warga negara yang memenuhi syarat untuk memilih dalam pemilihan umum haruslah dapat menyalurkan hak pilihnya.

Pemilihan umum (pemilu) telah menjadi sebuah fenomena global. Baik negara maju maupun berkembang, pemilu menjadi sarana terbaik untuk memfasilitasi pergantian kekuasaan yang damai. Namun demikian, praktek pemilu di berbagai negara di dunia menunjukkan variasi pelaksanaan yang beragam, dari yang dilaksanakan secara bebas dan adil sampai kepada penyelenggaraan pemilu yang penuh dengan pelanggaran dan kecurangan. Dari beragam fenomena empirik pelaksanaan pemilu tersebut, isu terkait integritas pemilu mengemuka dan menjadi perhatian banyak pihak . ${ }^{1}$

Salah satu permasalahan dalam pemilu adalah persoalan mengenai hak-hak konstitusional dari masyarakat penganut aliran kepercayaan lokal yang tidak diperkenankan untuk mencantumkan aliran kepercayaan mereka ke dalam Kartu Tanda Penduduk (KTP) dan apabila mereka ingin berurusan dengan dengan kegiatan yang bersifat adminitratif formil, mereka diharuskan untuk memilih salah satu dari ke-enam agama yang diakui di Indonesia. Ke-enam agama tersebut adalah: Islam, Protestan, Katholik, Hindu, Budha, dan Konghucu.

Masyarakat Penganut Kepercayaan Lokal yang merasakan ada pelanggaran hak konstitusional dengan pengaturan hukum pada Pasal 61 ayat (1), Pasal 64 ayat (1) dan ayat (5) Undang-Undang Nomor 24 tahun 2013 tentang Perubahan Atas UndangUndang Nomor 23 tahun 2006 tentang Administrasi Kependudukan ( UU Adminduk)

${ }^{1}$ Mudiyati Rahmatunnisa, Mengapa Integritas Pemilu Penting, Jurnal Bawaslu, Vol. 3 No. 12017 , ISSN 2443-2539, hlm. 2. 
khususnya terkait ketentuan pengosongan kolom agama bagi Penganut Kepercayaan Lokal di dalam Kartu Keluarga (KK) dan Kartu Tanda Penduduk.

Pada kenyataannya kelompok penghayat kepercayaan lokal mengalami diskriminasi akibat pengosongan kolom agama di Kartu Tanda Penduduk dan Kartu Keluarga. Beberapa peristiwa diskriminasi dari masyarakat mayoritas terjadi kepada penganut Sapto Darmo di Brebes, Jawa Tengah, yang kesulitan memakamkan keluarganya di pemakaman umum karena kolom agamanya kosong. Selain itu, terjadinya diskriminasi bagi penganut kepercayaan Marapu di Sumba, Nusa Tenggara Timur, yang tidak dapat mencatatkan perkawinannya di Catatan Sipil dan berakibat pada anak-anak penganut kepercayaan marapu di Sumba tidak memiliki akta kelahiran. Di Sumatera Utara, kelompok Parmalim dan Ugamo Bangso Batak, misalnya, kesulitan mendapatkan pekerjaan karena kolom agama mereka kosong. Dewi Kanti, penganut Sunda Wiwitan, menuturkan bahwa anak-anak penganut Sunda Wiwitan tidak jarang harus mengakui salah satu agama supaya bisa bersekolah. ${ }^{2}$ Keadaan tersebut merupakan bentuk diskriminasi yang terjadi dikarenakan masyarakat penganut kepercayaan lokal dianggap merupakan masyarakat yang tidak beragama seperti yang dianut oleh masyarakat mayoritas.

Berdasarkan Putusan Mahkamah Konstitusi Nomor Perkara 97/PUU-XIV/2016, Mahkamah Konstitusi mengabulkan permohonan uji materi Pasal 61 Ayat (1) dan (2), serta Pasal 64 Ayat (1) dan (5) Undang-Undang Nomor 23 Tahun 2006 tentang Administrasi Kependudukan juncto Undang-Undang Nomor 24 Tahun 2013 tentang Perubahan Atas Undang-Undang Nomor 23 Tahun 2006 tentang Administrasi Kependudukan.

\footnotetext{
2 Sabrina Asril (editor), "Pengosongan Kolom Agama Digugat", http://nasional.kompas.com/read/2016/10/06/15401061/pengosongan.kolom.agama.digugat, diakses tanggal 15 September 2018.
} 
Mahkamah Konstitusi berpendapat pertama, bahwa kata "agama" dalam Pasal 61 Ayat (1) dan Pasal 64 Ayat (1) bertentangan dengan UUD 1945 dan tidak mempunyai kekuatan hukum mengikat secara bersyarat sepanjang tidak termasuk penganut aliran kepercayaan. Artinya, penganut aliran kepercayaan memiliki kedudukan hukum yang sama dengan pemeluk enam agama yang telah diakui pemerintah dalam memperoleh hak terkait administrasi kependudukan. ${ }^{3}$

Putusan Mahkamah Konstitusi tersebut telah memberikan legitmasi bagi masyarakat penghayat kepercayaan lokal untuk mendapatkan pengakuan dan perlindungan terhadap hak-hak konstitusionalnya. Tetapi, sampai saat ini, putusan Mahkamah Konstitusi Nomor 97/PUU-XIV/2016, belum dapat diterapkan pada sistem administrasi kependudukan karena putusan tersebut hanya terkait dengan uji materi Undang-Undang administrasi kependudukan. Selain itu dalam kenyataan sosial masyarakat, keberadaan masyarakat penghayat kepercayaan lokal yang juga bagian dari warga negara Indonesia masih belum mendapatkan hak-hak sipil, politik, hukum dan pemerintahan secara utuh dan maksimal.

Berdasarkan latar belakang tersebut, penulis tertarik untuk melakukan penelitian dengan judul "Pemenuhan Hak Konstitusional Masyarakat Penganut Kepercayaan

\section{Lokal Dalam Pemilihan Umum”.}

\section{Rumusan Masalah}

Berdasarkan latar belakang diatas, maka penelitian ini mengkaji tentang Bagaimana Kedudukan Masyarakat Penganut Kepercayaan Lokal dalam sistem Kewarganegaraan Indonesia? Dan Bagaimana perlindungan hak konstitusional

${ }^{3}$ Estu Suryowati, "Putusan MK Membuat EksistensiPenghayat Kepercayaan Diakui Negara", http://nasional.kompas.com/read/2017/11/07/18573861/putusan-mk-membuat-eksistensi-penghayatkepercayaan-diakui-negara, diakses pada tanggal 15 September 2018. 
PEMENUHAN HAK KONSTITUSIONAL Muhammad Yusrizal Adi Syaputra, Mirza Nasution

penganut aliran kepercayaan lokal dalam pemilihan umum berdasarkan sistem ketatanegaraan Indonesia?

\section{B. HASIL DAN PEMBAHASAN}

\section{Kedudukan Masyarakat Penganut Kepercayaan Lokal Dalam Sistem} Kewarganegaraan Indonesia.

Indonesia adalah Negara yang terdiri atas beragama etnis suku yang berbeda-beda disetiap daerah. Menurut Van Vollenhoven yang membagi masyarakat nusantara menjadi beberapa klasifikasi daerah adat dalam 19 lingkungan Hukum Adat (adat rechtkringen). Berdasarkan 19 Lingkungan hukum adat menurut Van Vollen Hoven tersebut memiliki karakteristik adat istiadat dan budaya masyarakat yang berbeda-beda, misalnya antara Masyarakat Aceh dengan Masyarakat Jawa memiliki perbedaan budaya dan adat istiadat. Selain daripada Adat istiadat dan budaya, masing-masing masyarakat adat dilingkungan hukum adat tersebut memiliki perbedaan terhadap regiliusitas masyarakatnya. Ada masyarakat adat yang menganut agama seperti Islam, Hindu, Budha, Kristen dan juga ada masyarakat yang masih mempercayai agama nenek moyang atau yang disebut dengan Kepercayaan Lokal Masyarakat.

Indonesia sejak semula menjadi negara adalah negara yang dapat dikategorikan sebagai negara dengan konsep masyarakat madani. Menurut Jimlly Asshiddiqie, bahwa ciri-ciri masyarakat madani dapat dirumuskan ${ }^{4}$ :

1) Masyarakat madani itu adalah ruang publik yang bebas dan terbukua ( free and open public sphere) dalam masyarakat (a public space in soceity) yaitu antara negara dan keluarga;

\footnotetext{
4 Jimlly Asshiddiqie, Gagasan Konstitusi Sosial : Institusionalisasi dan Konstitusionalisasi Kehidupan Sosial Masyarakat Madani, LP3S, Jakarta, 2015, hlm. 142-143
} 
2) Masyarakatnya bersifat majemuk, tetapi toleran, mengutamakan kesederajatan, dan saling berhubungan;

3) Masyarakatnya berhimpun berdasarkan prinsip otonomi setiap individu dan kebebasan untuk berekspresi dan berorganisasi;

4) Interaksi sosial berlangsung secara adil dan teratur dengan menjunjung tinggi nilai-nilai dan norma hukum, etika, agama yang fungsional dalam kehidupan praktik;

5) Warga masyarakatnya menghormati dan menggandrungi ilmu pengetahuan teknologi;

6) Partisipasi sosial berkembang aktif dan terorganisasi untuk kepentingan bersama;

7) Keadilan sosial yang merata menyebabkan jarak sosial antara elit dan massa tidak timpang

Kemajemukan masyarakat Indonesia yang merupakan ciri dari masyarakat madani tidak hanya berdasarkan perbedaan suku, etnis tetapi juga keyakinan / agama terhadap tuhan. Selain agama mayoritas, ternyata masih ada masyarakat Indonesia yang menganut agama nenek moyang atau yang disebut agama lokal. Hal ini juga menunjukkan bahwa masyarakat Indonesia tersusun dengan beraneka kemajemukan masyarakat yang menjadi dasar terbentuknya semboyan negara bhineka tunggal ika.

Agama Lokal Nusantara merupakan sistem keyakinan yang dianut, dihayati dan dijalankan secara turun-temurun oleh masyarakat nusantara jauh sebelum masuk agamaagama yang datang kemudian. Kepercayaan Lokal yang disebut sebagai Agama Asli 
masyarakat Nusantara merupakan sistem spiritualitas asli yang tidak bercampur dengan agama-agama lain yang datang ke Nusantara kemudian ${ }^{5}$.

Berdasarkan kenyataannya, bahwa secara sosiologis bahwa konsep agama asli adalah realitas yang ada dan ditemukan di tengah masyarakat nusantara untuk berkeyakinan terhadap tuhan melalui tata cara adat kebudayaan lokal masyarakat asli nusantara yang dianut turun temurun jauh sebelum agama-agama mayoritas masuk ke nusantara.

Menurut Subagya, bahwa Penghayat Kepercayaan Lokal dapat dikategorikan dalam dua kelompok berar yakni ${ }^{6}$;

1) Kelompok yang diidentifikasikan golongan Propomelayu, yakni agama-agama asli yang terus berlangsung sampai saat ini dan tanpa dipengaruhi agamaagama luar yang datang. Mereka kemudian disebut sebagai suku bangsa terasing.

2) Kelompok yang di identifikasikan golongan Deutromelayu, yakni Penghayat Kepercayaan yang bergerak dalam pusaran agama-agama pendatang yang dominan, terutama yang terjadi di Jawa. Meskipun terdapat pengaruh dari luar, namun unsur lokalitas tetap dipertahankan dengan menyamar (incognito), atau singkretik sebagai mekanisme pertahanan diri (defensive).

Secara umum masyarakat Indonesia mengakui secara mayoritas ada enam agama yang diakui di Indonesia seperti : Islam, Katolik, Protestan, Hindu, Budha, dan hlm. 1.

${ }^{5}$ Rachmat Subagya, Agama Asli Indonesia, Jakarta: Sinar Harapan \& Yayasan Citraloka, 1981,

${ }^{6}$ Subagya dalam Sudarto, Seri Laporan Kebebasan Beragama/Berkeyakinan: Kondisi Pemenuhan Hak Konstitusional Penghayat Kepercayaan Terhadap Tuhan Yang Maha Esa, Pustaka Masyarakat Setara, Jakarta, 2017, hlm, 13-14 
Konghucu, sebenarnya tidak ada pengaturan yang secara tegas menyebutkan bahwa keenam agama tersebut merupakan agama resmi yang diakui di Indonesia.

Status pengakuan keenam agama tersebut didapatkan dari penjelasan Pasal 1 Penetapan Presiden Republik Indonesia Nomor 1/PNPS Tahun 1965 Tentang Pencegahan Penyalahgunaan Dan/Atau Penodaan Agama, yang berbunyi : “Agamaagama yang dipeluk oleh penduduk di Indonesia ialah Islam, Kristen, Katolik, Hindu, Budha dan Khong $\mathrm{Cu}$ (Confusius). Hal ini dapat dibuktikan dalam sejarah perkembangan agama-agama di Indonesia.

Berdasarkan fakta historis bahwa mayoritas warga negara Indonesa memeluk 6 agama (Islam, Hindu, Budha, Kristen Katolik, Kristen Protestan, dan Kong $\mathrm{Hu}$ chu) yang telah berkembang pesat di tengah masyarakat Indonesia.

Berdasarkan UUD 1945 sebagai hukum tertinggi Indonesia, bahwa hak mengenai kebebeasan memeluk agama dan keyakinan terhadap tuhan di jamin oleh Negara sebagaimana yang diatur ada Pasal 29 ayat 2 UUD 1945.

Diluar masyarakat penganut agama, terdapat kelompokm masyarakat penganut kepercayaan lokal berdasarkan Penetapan Presiden Republik Indonesia Nomor 1/PNPS Tahun 1965 Tentang Pencegahan Penyalahgunaan Dan/Atau Penodaan Agama sebagai salah satu bentuk politik hukum pemerintahan Orde Baru untuk mensiasati dan mencegah berkembangnnya ajaran / ideologi yang bertentangan dengan nilai-nilai Pancasila dan UUD 1945. Hal ini merupakan reaksi Pemerintah Orde Baru karena Pemberontakan Partai Komunis Indonesia tahun 1965 yang berbasiskan paham komunis sebagai bentuk ideologi partainya.

Politik hukum pemerintah Indonesia melalui PNPS No. 1 tahun 1965 memberikan dampak pada masyarakat penganut kepercayaan lokal yang dianggap tidak beragama 
untuk memberikan pengarahan kepada pandangan yang sehat dan kearah Ketuhanan yang Maha Esa.

Setelah Reformasi, Pemerintah Indonesia berdasarkan Peraturan bersama Menteri Dalam Negeri dan Kebudayaan dan Menteri Kebudayaan Pariwisata N. 41/43 tahun 2009 tentang Pedoman Pelayanan kepada Penghayat Kepercayaan Terhadap Tuhan yang Maha Esa menjelaskan bahwa Penghayat Kepercayaan merupakan Pernyataan dan pelaksanaan hubungan pribadi dengan Tuhan Yang Maha Esa berdasarkan keyakinan yang diwujudkan dengan perilaku ketaqwaan dan peribadatan terhadap Tuhan Yang Maha Esa serta pengamalan budi luhur yang ajarannya bersumber dari kearifan lokal bangsa Indonesia.

Masyarakat penghayat kepercayaan lokal adalah bagian dari warga negara Indonesia yang memiliki hak-hak konstitusional sebagaimana warga negara yang mempercayai kepercayaan dalam bentuk agama-agama mayoritas lainnya. Oleh karena itu, Pemerintah Indonesia harus memberikan perlindungan dan pemenuhan hak-hak konstitusional masyarakat sesuai berdasarkan nilai-nilai Pancasila dan UUD 1945 serta norma-norma hukum lain yang ada.

Tetapi dalam kenyataannya, Negara membedakan hak-hak setiap warga negara dan secara inklusif diberikan kepada kepada kelompok warga negara tertentu. Setelah Reformasi Indonesia, Pemerintah Indonesia melaksanakan sistem kewarganegaraan dengan paradoks tertentu. Di satu sisi, secara tertulis undang-undang dan peraturan baru telah memperluas hak-hak warga negara. Namun, di sisi lain, kemampuan warga negara untuk benar-benar mewujudkan hak-hak nya tidak meningkat, bahkan menurun dibeberapa daerah. Misalnya lahirnya Undang-Undang Pers, Undang-Undang Buruh, Undang-Undang Kewarganegaraan, Undang-Undang Kebebasan Informasi, Undang- 
Undang Jaminan Sosial dan layanan Kesehatan, Undang-Undang Bantuan hukum dan Undang-Undang Administrasi Kependudukan, serta Undang-Undang Pemilihan Umum secara substansial telah memperkuat kekuatan warga negara ketika berhadapan dengan otoritas negara.

Disisi lain, warga negara seringkali tidak dapat mewujudkan hak-haknya walapun secara substansi sudah diatur dalam undang-undang. Koneksi politik dan kepentingan kelompok pemilik modal dan elit politik telah menimbulkan kesenjangan dan antara hukum dan kebijakan dalam pemerintahan yang akhirnya menimbulkan pelemahan dari supremasi hukum. Masyarakat sebagai warga negara akan tidak sama kedudukannya dalam praktik dalam mewujudkan hak-hak konstitusionalnya sebagai warga negara Indonesia.

Di Indonesia, Identitas sosial seperti agama dan etnis membentuk cara warga negara dan negara Indonesia saling berhubungan. Gagasan tentang "komunitas tradisional" telah menjadi soko guru retrorika politik dan cara klaim hak-hak warga negara dirumuskan ${ }^{7}$. Klaim atas tanah, pergumulan politik dalam pemilihan umum, perlindungan hukum serta persoalan pekerjaan selalu di identikkan dengan etnis dan agama dari masyarakat tertentu. Hal itulah yang menjadi pemicu konflik ditengah masyarakat Indonesia. Diskriminasi rasial, etnis dan agama menjadi bahan dan alat dari elit-elit politik untuk memperoleh kekuasaan negara, dan pada akhirnya masyarakat yang menjadi korban.

2. Perlindungan Hak-Hak Konstitusional Masyarakat Penghayat Kepercayaan Lokal di Indonesia Dalam Pelaksanaan Pemilihan Umum

${ }^{7}$ Ward Barenschot dan Gerry Van Klinken (Penyunting), Citizenship in Indonesia: Perjuangan atas Hak, Identitas, dan Partisipasi, Hanato P. Sudarhto (Penerjemah), Yayasan Pustaka Obor Indonesia, Jakarta, 2019, hlm.25-26 
Warga Negara adalah salah satu syarat de facto terbentuknya negara. Warga negara yang bertempat tinggal di suatu daerah yang kemudian membentuk sistem interaksi sosial melalui sistem dan struktur kemasyarakatan.

Struktur masyarakat Indonesia ditandai oleh dua cirinya yang bersifat unik. Pertama, secara horizontal, masyarakat Indonesia ditandai oleh kenyataan adanya kesatuan-kesatuan sosial berdasarkan perbedaan-perbedaan suku bangsa, perbedaan agama, serta perbedaan kedaerahan. Secara vertikal, struktur masyarakat Indonesia ditandai oleh adanya perbedaan-perbedaan vertikal antara lapisan atas dan lapisan bawah yang cukup tajam ${ }^{8}$

Menurut Elly M. Setiadi dan Usman Kolip bahwa sistem kemasyarakatan Indonesia juga terjadi pembedaan ditengah masyarakat itu atau yang disebut dengan diferensiasi sosial. Diferensiasi sosial dipahami sebagai pembeda/pemilah masyarakat ke dalam golongan atau kelompok secara horizontal (tidak secara bertingkat) ${ }^{9}$

Diferensiasi sosial muncul akibat dari pembagian pekerjaan (seperti di dalam masyarakat modren), perbedaan jenis kelamin, suku (pengelompokan individu atas dasar ciri persamaan kultur seperti; bahasa, adat istiadat, sejarah, sikap, wilayah, dan sebagainya), agama, ras (pengelompokan individu atas dasar ciri-ciri fisiologis), profesi dan sebagainya tidak bersifat hierarkis tetapi bersifat sejajar (horizontal). Stratifikasi lebih dipahami sebagai gejala sosial dimana ketimpagan distribusi dan kelangkaan benda-benda berharga yang dibutuhkan masyarakat terbagi secara tidak merata.

${ }^{8}$ Nasikun, Sistem Sosial Indonesia, Rajawali Press, Jakarta, 2015, hlm. 34

9 Elly M. Setiadi dan Usman Kolip, Pengantar Ssiologi, Pemahaman Fakta Dan Gejala Permasalahan Sosial: Teori Aplikasi, Dan Pemecahannya, Jakarta: Kencana, Cetakan Pertama, 2011, hlm. 459-460. 
Sehingga menimbulkan perbedaan kelompok secara hierarkis yang dalam terminasi sosiologi disebut pelapisan sosial atau diferensiasi sosial ${ }^{10}$.

Pada kenyataannya, kemajemukan masyarakat Indonesia secara normatif akan menimbulkan seperangkat hak dan kewajiban yang sama di mata hukum. Namun, kenyataannya, kemajemukan masyarakat/diferensiasi sosial akan menimbulkan stratifikasi sosial dalam masyarakat berdasarkan sistem kekuasaan, ekonomi, kedudukan sosial, pendidikan, profesi/pekerjaan dan lain sebagainya.

Ada dua proses yang mempengaruhi perilaku kelompok secara mendalam dan menyeluruh: ${ }^{11}$

1. Integrasi sosial, yakni kecenderungan untuk saling menarik dari berbagai bentuk keragaman sosiokultural yang ada. Kecenderungan tersebut didorong oleh adanya tingkat ketergantungan di antara kelompok-kelompok yang beragam tersebut di dalam memenuhi kepentingan bersama. Keadaan tersebut akan menimbulkan sikap saling menyesuaikan diri di antara kelompokkelompok yang beragam, hingga akhirnya terbentuk integrasi sosial.

2. Diferensiasi sosial, yakni kecenderungan ke arah perkembangan sosial yang berlawanan seperti pembedaan menurut ciri-ciri biologis antar manusia atau atas dasar agama, jenis kelamin, dan profesi.

Sistem kemasyarakatan yang majemuk di negara Indonesia menjadikan negara Indonesia tidak dapat menyeragamkan kepentingan nasional tanpa terlebih dahulu memperhatikan kebutuhan, kepentingan, serta hak dari masyarakat didaerah-daerah memiliki kekhususan disetiap daerahnya. Oleh karena itu, melalui kebijakan Nasional Pemerintah memerlukan pendalaman, dan kajian-kajian sosial, ekonomi, hukum dan

\footnotetext{
${ }^{10}$ Ibid.

${ }^{11}$ Ibid, hlm. 460.
} 
politik terhadap kepentingan-kepentingan masyarakat. Hal tersebut merupakan bentuk penjelmaan fungsi dan peran sebuah negara untuk mewujudkan negara yang sejahtera, dan berdasarkan atas hukum.

Konsep Negara bukan sebatas teritorial bangsa yang memiliki kedaulatan penuh karena wilayah hanya sebagian kecil dari negara. Bagian terbesar dan paling substansial dari negara adalah kesatuan dari politik. Negara adalah institusi dasar dari kekuasaan politik. Oleh karena itu, negara merupakan hukum, wilayah kekuasaan, konstitusi, masyarakat, dan tujuan. Negara bukan sesuatu yang konkret, melainkan konsep abstrak tentang sikap politik dan kekuasaan yang terkandung di dalamnya. ${ }^{12}$

Negara merupakan bentuk organisasi sekelompok atau beberapa kelompok manusia secara bersama yang kemudian bertempat tinggal mendiami wilayah tertentu dan didalamnya memiliki pemerintahan yang mengurus tata tertib dan keselamatan mereka. ${ }^{13}$

Pemahaman tentang eksistensi negara dan eksistensi manusia, sama dengan pandangan bahwa komunitas sosial berarti kesatuan beragam individu dan tindakan sejumlah individu yang menjadi latar belakang dibutuhkannya norma-norma bernegara. Inilah yang menegaskan bahwa negara bukan semata-mata realitas hukum, tetapi realitas sosial. Realitas hukum menghendaki keberadaan realitas sosial yang diakui oleh hukum, sedangkan realitas hukum sebagai realitas yang ingin ditaati oleh realitas sosial. $^{14}$

Konsep rakyat dalam pembukaan alinea ke dua UUD 1945. Pada alinea keempat UUD 1945 juga menyebutkan konsep rakyat untuk menunjukkan konsep kedaulatan hlm.55-56.

12 Zulkarnaen dan Beni Ahmad Saebani, Hukum Konstitusi, Bandung: Pustaka Setia, 2012,

${ }^{13}$ Mirza Nasution dalam Zulkarnaen dan Beni Ahmad Saebani, Hukum Konstitusi, Ibid, hlm. 55.

${ }^{14}$ Ibid, hlm. 57 
rakyat/demokrasi sebagai dasar pembentukan negara Republik Indonesia. Penegasan kembali Kedaulatan rakyat diatur dalam Pasal 1 ayat (2) UUD 1945. ${ }^{15}$

Berdasarkan konsep rakyat sebagaimana yang dicantumkan dalam pembukaan UUD 1945 adalah seluruh manusia yang mendiami wilayah Indonesia tanpa memandang suku, ras, agama, dan kepercayaan adalah rakyat Indonesia yang harus mendapatkan kemerdakan menjadi masyarkat yang merdeka melalui berdirinya Republik Indonesia. Kemerdakaan Indonesia menjadi sebuah negara harus memberikan kebahagiaan lahir dan batin bagi seluruh rakyat Indonesia tanpa ada diskriminasi dalam bentuk apapun.

Sesuai dengan sila pertama Pancasila, Negara Hukum Indonesia haruslah mengandung prinsip Ketuhanan Yang Maha Esa. Hal ini ditegaskan dalam Pasal 29 ayat (1) UUD 1945 yang berbunyi "Negara berdasarkan atas Ketuhanan Yang Maha Esa". Oleh karena itu, sistem hukum dan cita Negara Hukum Indonesia harus pula Berketuhanan yang Maha Esa. Hal ini sejalan dengan pengakuan bangsa Indonesia akan Kemahakuasaan Tuhan Yang Maha Esa seperti yang tercermin dalam kalimat pembuka alinea ketiga Pembukaan Undang-Undang Dasar 1945.

Terdapat tiga doktrin kedaulatan yang dianut oleh Undang-Undang Dasar 1945 secara simultan, pertama doktrin Kedaulatan Rakyat atau demokrasi seperti yang tercermin dalam alinea keempat pembukaan Undang-Undang Dasar 1945 dan Pasal 1 ayat (2) Undang-Undang Dasar, kedua doktrin Kedaulatan Hukum atau nomokrasi seperti yang tercermin dalam alinea keempat pembukaan Undang-Undang Dasar dan Pasal 1 ayat (3) Undang-Undang Dasar, ketiga doktrin Kedaulatan Tuhan atau

\footnotetext{
${ }^{15}$ Daniel Zuchron, Menggugat Manusia Dalam Konstitusi: Kajian Filsafat Atas UUD 1945 Pasca Amandemen, Jakarta Timur: Rayyana Komunikasindo, 2017, hlm. 87-89.
} 
Kemahakuasaan seperti tercermin dalam alinea ketiga dan keempat pembukaan Undang-Undang Dasar serta Pasal 29 ayat (1) Undang-Undang Dasar. ${ }^{16}$

Berdasarkan ketentuan konstitusi tersebut, maka kewajiban negara untuk mengakomodir kebutuhan serta jaminan perlindungan bagi rakyatnya. Kebutuhan, termasuk di dalamnya kebutuhan rohani atau spiritual dan jaminan untuk dapat melaksanakan ibadah sesuai dengan agama dan kepercayaannya masing-masing tanpa rasa takut.

Selama tujuh dekade terakhir, Indonesia telah mengalami proses demokrasi yang lambat, sejak proklamasi kemerdekaan 17 Agustus 1945, hampir 5 dekade Indonesia dipimpin oleh rezim yang otoriter. Ini Tak dapat dipungkiri bahwa pergeseran dalam rezim politik semacam itu merupakan hasil yang berat sejak masa Demokrasi Terpimpin dan Demokrasi Pancasila. Selama periode ketika rezim otoriter mengendalikan ekonomi nasional dan kepentingan politik, korupsi merajalela dan meluas di seluruh birokrasi, yang akhirnya menyebabkan Indonesia menderita secara signifikan selama krisis keuangan Asia. Kondisi ini menyebabkan keresahan yang mengakibatkan apa yang terjadi sekarang dikenal sebagai Reformasi. Reformasi menjadi transformasi konstitusional yang membuat konstitusi Indonesia lebih komprehensif dan termasuk jaminan perlindungan hak warga negara dan pembatasan kekuasaan lembaga negara. ${ }^{17}$

Salah satu hak konstitusional warga negara adalah bidang politik. Perwujudan hak konstitusional dibidang politik adalah melalui pemilihan umum. Pemilihan umum adalah sarana suksesi atau pergantian kepemimpinan pemerintahan di Indonesia di

${ }^{16}$ Jimly Asshiddiqie, Konstitusi Dan Konstitusionalisme Indonesia, Jakarta Timur: Sinar Grafika, 2010, hlm.134.

${ }^{17}$ Muhammad Bahrul Ulum dan Nilna Aliyan Hamida, Revisiting Liberal Democracy and Asian Values in Contemporary Indonesia, Jurnal Constitutional Review, Volume 4, Number 1, Mei 2018, ISSN: 2460-0016, hlm. 112. 
Lembaga Legislatif (DPR, DPD dan DPRD) dan Eksekutif (Presiden/Wakil Presiden dan Kepala Daerah).

Setiap warga negara Indonesia memilki hak yang sama untuk ikut serta dalam pemilihan umum baik sebagai calon ataupun pemilih. Pelaksanaan perlindungan terhadap hak-hak konstitusional warga negara Indonesia melalui konstitusi dan peraturan perundang-undangan dibawahnya telah mengalami pasang surut khususnya mengenai sistem pemilihan umum di Indonesia.

Situasi politik Indonesia yang dipengaruhi sistem sosial masyarakat Indonesia menjadi dasar bagi Pemerintah Indonesia untuk membentuk regulasi-regulasi setingkat Undang-Undang untuk menentukan bentuk dan sistem pelaksanaan pemilihan umum dari masa ke masa.

Berdasarkan sistem pemilihan umum di tahun 2019, terbentuk paradigma baru yakni dalam kehidupan berpartai dan proses pendukungan calon-calon anggota legislatif ataupun dalam pelaksanaan pemilihan presiden/wakil presiden. Isu kemajemukan masyarakat Indonesia (mulai dari agama, suku, kedaerahan) menjadi bahan kampanye calon-calon anggota legislatif dan eksekutif yang berujung pada terpecahnya masyarakat Indonesia. Masyarakat Indonesia menjadi terbelah dalam memberikan dukungan kepada masing-masing calon legislatif ataupun presiden/wakil presiden yang diusungnya.

Pemilihan umum merupakan sarana konsolidasi dalam transisi demokrasi untuk mengorganisir dan membentuk civil society, political society, economic society, state apparatus, dan rule of law. ${ }^{18}$ Pemilihan umum seharusnya dapat mengakomodir semua hak-hak konstitusional warga negara Indonesia untuk dapat berpartisipasi.

\footnotetext{
${ }^{18}$ M. Fadjroel Rachman, Demokrasi Tanpa Kaum Demokrat, Koekoesan, Jakarta, 2007, hlm. 38
} 
Menurut Jhon Locke dan Rosseau bahwa pemilihan umum dilahirkan dari konsepsi dan gagasan besar mengenai demokrasi yang terdapat didalamnya kebebasan, keadilan, kesetaraan individu dalam segala bidang. ${ }^{19}$ Terbentuknya tatanan demokrasi sebuah negara berawal dari proses pemilihan umum. Pemilihan umum didasarkan asas langsung, umum, bebas, rahasia, jujur dan adil sebagaimana yang diatur pada Pasal 2 Undang-Undang Nomor 7 tahun 2017 tentang Pemilihan Umum.

Pemilihan umum yang didasarkan atas dasar adil harus memberikan kesempatan kepada setiap warga negara Indonesia untuk melaksanakan hak konstitusionalnya di bidang politik baik sebagai peserta ataupun pemilih. Pemenuhan asas adil dalam pelaksanaan pemilihan umum di Indonesia harus dapat dirasakan dan dilaksanakan oleh setiap lapisan masyarakat Indonesia yang tersebar diseluruh wilayah Negara Kesatuan Republik Indonesia.

Di dalam pelaksanaan pemilihan umum tahun 2019, masyarakat penganut kepercayaan lokal yang notebene nya masih bertempat tinggal di daerah-daerah terpencil diwilayah Indonesia hanya dilibatkan dalam pemilihan umum melalui pengisian formulir C-4 atau undangan untuk memilih. Kondisi ironis seperti ini diamati tokoh penghayat kepercayaan Sunda Wiwitan Dewi Kanti Setianingsih masih terjadi di daerah dan angkanya cukup tinggi ${ }^{20}$.

Berdasarkan data yang dikutip dari Aliansi Masyarakat Adat Nusantara (AMAN), sebanyak tiga juta anggotanya tidak masuk dalam daftar pemilih tetap (DPT) pada pemilihan presiden dan pemilihan calon legislatif pada Rabu, 17 April 2019. Musababnya karena terganjal KTP lantaran menghuni di kawasan hutan negara

\footnotetext{
19 Siti Faridah, Jerico Mathias, Politisasi Agama Pemecah Keutuhan Bangsa dalam Pemilu, Seminar Nasional Hukum Universitas Negeri Semarang, Volume 4 Nomor 3 Tahun 2018, hlm. 493

$20 \mathrm{https} / / /$ www.validnews.id/Balada--Pemilu--Penghayat--Kepercayaan-KOb, diakses tanggal 10 Juni 2019, Pukul.21.00 wib, di Kota Medan
} 
dengan status sengketa. Ada juga yang tidak punya KTP karena persoalan aliran kepercayaan yang belum bisa dicantumkan. Sebanyak 1,6 dari 3 juta penghayat kepercayaan tercatat tidak masuk dalam DPT karena belum mengantongi KTP. Angka tersebut belum termasuk 5.000 lebih komunitas penganut kepercayaan lainnya yang tidak bergabung dengan AMAN dengan perkiraan jumlah populasi mencapai 70 juta jiwa $^{21}$.

Setelah diterbitkannya Putusan Mahkamah Konstitusi Nomor perkara 97/PUU$\mathrm{XIV} / 2016$, penganut aliran kepercayaan dapat menjadi pemilih dalam pemilihan umum tanpa harus mengadopsi salah satu dari ke-enam agama yang diakui di Indonesia, akan tetapi untuk menjadi calon anggota legislatif maupun menjadi calon presiden dan wakil presiden, masih harus dilakukan telaah lebih lanjut melalui keputusan Mahkamah Konstitusi, karena sampai saat ini masyarakat Indonesia masih menilai bahwa penganut aliran kepercayaan tidaklah bertaqwa kepada Tuhan Yang Maha Esa, bertakwa kepada Tuhan Yang Maha Esa Merupakan syarat mutlak untuk menjadi calon anggota legislatif dan calon presiden/wakil presiden. Selain itu, hak konstitusional masyarakat penganut kepercayaan lokal dalam bidang politik harus difasilitasi negara yang dilaksanakan pemerintah pusat, pemerintah daerah, dan Partai Politik sebagai infrastruktur dan suprastrukutr politik negara Indonesia.

Pendidikan politik harus diberikan kepada setiap masyarakat penghayat kepercayaan lokal agar masyarakat penghayat kepercayaan lokal tersebut dapat tercerdaskan dalam politik sehingga tidak hanya menjadi korban para elite politik yang akan hanya akan datang di saat menjelang pelaksanaan pemilihan umum, dan setelah

\footnotetext{
${ }^{21}$ Ibid.
} 
pemilihan umum selesai, maka para elite politik tersebut tidak merealisasikan janji politiknya.

Pemerintah dan Para elite politik seharusnya mengakomodir hak-hak konstitusional masyarakat penghayat kepercayaan lokal sebagai bentuk keseriusan dan wujud pelaksanaan tujuan bernegara Republik Indonesia yang melindungi segenap bangsa Indonesia.

\section{SIMPULAN}

Berdasarkan hasil pembahasan maka dapat diperoleh kesimpulan sebagai berikut:

1. Kedudukan Masyarakat Penganut Kepercayaan Lokal Dalam Sistem Kewarganegaraan Indonesia adalah bagian dari warga negara Indonesia yang dilindungi berdasarkan konstitusi dan undang-undang kewarganegaraan Indonesia (UU No. 12 tahun 2006). Oleh karena itu, Negara wajib memenuhi hak dari masyarakat penganut kepercayaan lokal dalam segala bidang.

2. Setelah diterbitkannya Putusan Mahkamah Konstitusi Nomor perkara 97/PUU-XIV/2016, penganut aliran kepercayaan dapat menjadi pemilih dalam pemilihan umum tanpa harus mengadopsi salah satu dari ke-enam agama yang diakui di Indonesia, hanya saja dalam proses pemilihan umum pemerintah tidak memberikan KTP Elektronik melainkan memberikan formulis C4 kepada masyarakat penganut kepercayaan lokal untuk digunakan sebagai Data Pemilih. Oleh karena itu, dalam pelaksanaan pemilihan umum, masyarakat penganut kepercayaan lokal belum diakomodir hak konstitusionalnya secara penuh dan maksimal. 


\section{DAFTAR PUSTAKA}

Beni Ahmad Saebani, 2012, Hukum Konstitusi, Bandung: Pustaka Setia.

Daniel Zuchron, 2017, Menggugat Manusia Dalam Konstitusi: Kajian Filsafat Atas UUD 1945 Pasca Amandemen, Rayyana Komunikasindo: Jakarta.

Elly M. Setiadi dan Usman Kolip, 2011, Pengantar Ssiologi, Pemahaman Fakta Dan Gejala Permasalahan Sosial: Teori Aplikasi, Dan Pemecahannya, Jakarta: Kencana, Cetakan I.

Jimly Asshiddiqie, 2010, Konstitusi Dan Konstitusionalisme Indonesia, Sinar Grafika: Jakarta.

, 2015, Gagasan Konstitusi Sosial : Institusionalisasi dan Konstitusionalisasi Kehidupan Sosial Masyarakat Madani, LP3S: Jakarta.

M. Fadjroel Rachman, 2007, Demokrasi Tanpa Kaum Demokrat, Koekoesan: Jakarta.

Nasikun, 2015, Sistem Sosial Indonesia, Jakarta: Rajawali Press.

Rachmat Subagya, 1981, Agama Asli Indonesia, Sinar Harapan \& Yayasan Citraloka: Jakarta.

Sudarto, 2017, Seri Laporan Kebebasan Beragama/Berkeyakinan: Kondisi Pemenuhan Hak Konstitusional Penghayat Kepercayaan Terhadap Tuhan Yang Maha Esa, Pustaka Masyarakat Setara: Jakarta.

Ward Barenschot dan Gerry Van Klinken (Penyunting), 2019, Citizenship in Indonesia: Perjuangan atas Hak, Identitas, dan Partisipasi, Hanato P. Sudarhto

\section{Jurnal} (Penerjemah), Jakarta: Yayasan Pustaka Obor Indonesia.

Mudiyati Rahmatunnisa, Mengapa Integritas Pemilu Penting, Jurnal Bawaslu, Vol. 3 No. 12017

Muhammad Bahrul Ulum dan Nilna Aliyan Hamida, Revisiting Liberal Democracy and Asian Values in Contemporary Indonesia, Jurnal Constitutional Review, Volume 4, Number 1, Mei 2018.

Siti Faridah, Jerico Mathias, Politisasi Agama Pemecah Keutuhan Bangsa dalam Pemilu, Seminar Nasional Hukum Universitas Negeri Semarang, Volume 4 Nomor 3 Tahun 2018.

\section{Internet}

Sabrina Asril (editor), "Pengosongan Kolom Agama Digugat", http://nasional.kompas.com/read/2016/10/06/15401061/pengosongan.kolom.agam a.digugat, diakses tanggal 15 September 2018

Estu Suryowati, "Putusan MK Membuat EksistensiPenghayat Kepercayaan Diakui Negara", $\quad$ http://nasional.kompas.com/read/2017/11/07/18573861/putusan-mkmembuat-eksistensi-penghayat-kepercayaan-diakui-negara, diakses pada tanggal 15 September 2018

https://www.validnews.id/Balada--Pemilu--Penghayat--Kepercayaan-KOb, diakses tanggal 10 Juni 2019, Pukul.21.00 wib, di Kota Medan

\section{Peraturan Perundang-Undangan}

Undang-Undang Dasar Negara Republik Indonesia tahun 1945

Undang-Undang Nomor 12 tahun 2006 tentang Kewarganegaraan Republik Indonesia

Undang-Undang Nomor 7 tahun 2017 tentang Pemilihan Umum

Undang-Undang Nomor 24 tahun 2003 Tentang Mahkamah Konstitusi

Putusan Mahkamah Konstitusi Nomor perkara 97/PUU-XIV/2016 